\title{
Mutant IDH1 is required for IDH1 mutated tumor cell growth
}

\author{
Genglin Jin ${ }^{1}$, Christopher J. Pirozzi ${ }^{1}$, Lee H. Chen ${ }^{1}$, Giselle Y. Lopez ${ }^{1}$, Christopher \\ G. Duncan' ${ }^{1}$, Jie Feng ${ }^{1}$, Ivan Spasojevic ${ }^{2}$, Darell D. Bigner ${ }^{1}$, Yiping $\mathrm{He}^{1}$, and Hai \\ Yan ${ }^{1}$ \\ 1 The Preston Robert Tisch Brain Tumor Center, The Pediatric Brain Tumor Foundation Institute, and The Department of \\ Pathology, \\ 2 The Clinical Pharmacology Laboratory, Duke Cancer Institute and Department of Medicine/Oncology, Duke University \\ Medical Center, Durham, North Carolina, USA
}

Correspondence to: Hai Yan, email: hai.yan@duke.edu

Keywords: IDHI, cell survival

Received: July 27, 2012, Accepted: August 04, 2012, $\quad$ Published: August 09, 2012

Copyright: $\odot$ Jin et al. This is an open-access article distributed under the terms of the Creative Commons Attribution License, which permits unrestricted use, distribution, and reproduction in any medium, provided the original author and source are credited.

\section{ABSTRACT:}

\begin{abstract}
Frequent somatic hotspot mutations in isocitrate dehydrogenase 1 (IDH1) have been identified in gliomas, acute myeloid leukemias, chondrosarcomas, and other cancers, providing a likely avenue for targeted cancer therapy. However, whether mutant IDH1 protein is required for maintaining IDH1 mutated tumor cell growth remains unknown. Here, using a genetically engineered inducible system, we report that selective suppression of endogenous mutant IDH1 expression in HT1080, a fibrosarcoma cell line with a native IDH1 ${ }^{R 132 C}$ heterozygous mutation, significantly inhibits cell proliferation and decreases clonogenic potential. Our findings offer insights into changes that may contribute to the inhibition of cell proliferation and offer a strong preclinical rationale for utilizing mutant IDH1 as a valid therapeutic target.
\end{abstract}

\section{INTRODUCTION}

Genome-wide mutational analyses have revealed somatic mutations in the cytosolic NADP+-dependent isocitrate dehydrogenase 1 (IDH1) in $12 \%$ of glioblastoma multiforme (GBM) patients [1]. Further studies identified mutations in IDHI affecting amino acid 132 in over $70 \%$ of WHO grade II and III astrocytomas, oligodendrogliomas, and secondary glioblastomas [24]. Less frequently, mutations have been identified in the homologous mitochondria-associated $\mathrm{IDH} 2$ at the analogous amino acid residue (R172) [3, 5]. Following the discovery of these mutations at a surprisingly high frequency in low grade gliomas, IDH1 and IDH2 mutations were subsequently observed in several other cancers and syndromes, including acute myeloid leukemia [6-8], preleukemic clonal malignancies [9], central and periosteal cartilaginous tumors [10], intrahepatic origin cholangiocarcinomas [11], Ollier disease and Maffucci syndrome $[12,13]$. More rarely, $I D H 1$ and $I D H 2$ mutations have been reported in prostate cancer [14], B-acute lymphoblastic leukemia [14], colorectal cancer [15] and melanoma [16]. Additionally, $I D H 2$ germline mutations were detected in some patients with D-2-hydroxyglutaric aciduria [17]. The presence of mutations in IDHI and $I D H 2$ early in disease pathogenesis in malignant gliomas, myeloid malignancies, and cartilaginous tumors underscores the magnitude of the role of $I D H 1$ and $I D H 2$ mutations in tumorigenesis $[18,19]$.

Mutations in the active site of IDH1 (R132) and IDH2 (R172) impair the conversion of isocitrate to $\alpha$-ketoglutarate $(\alpha \mathrm{KG}) \quad[3,20]$. Metabolic profiling has identified a neomorphic activity in the presence of the mutant enzyme, namely, generation of a novel onco-metabolite, D-2-hydroxyglutarate (D-2HG) [4, 21]. Additionally, elevated D-2HG levels were found in AML and brain tumor patients with $I D H 1$ and $I D H 2$ mutations [21-23]. Nonetheless, the ramifications of these mutations remain largely unclear, and research is only recently starting to uncover some of the potential roles these mutations may play. D-2HG is structurally similar to $\alpha \mathrm{KG}$, and thus may act through the inhibition of enzymes requiring $\alpha \mathrm{KG}$. Large-scale analyses of genome-wide DNA methylation patterns in human gliomas found that $I D H 1 / 2$ mutations were associated with a highly specific DNA methylation profile [24-26]. It 
has been postulated that the changes in methylation may be due to D-2HG-mediated inhibition of multiple $\alpha \mathrm{KG}$ dependent dioxygenases, including the Tet oncogene family (TET) of 5-methylcytosine $(5 \mathrm{mC})$ hydroxylases and histone demethylases, resulting in increased histone methylation and decreased 5-hydroxymethylcytosine (5hmC) modifications [27, 28]. Further studies confirmed that mutant IDH1 impairs histone demethylation and is sufficient to establish the glioma hypermethylator phenotype, resulting in a block to cell differentiation [29].

The high frequency of $I D H 1$ and $I D H 2$ mutations in certain cancers, and the specificity of the genetic alterations to a limited set of amino acid residues, makes the mutant IDH1 or IDH2 product a tempting target for therapy. However, the role and contribution of mutant IDH1 or IDH2 in tumor initiation and/or maintenance remains largely unresolved, with findings from different groups yielding conflicting results. While one group reported increased growth in vivo in a melanoma cell line transfected with mutant IDH1 [30], another group reported a decrease in proliferation in glioma cell lines both in vitro and in vivo in the presence of mutant IDH1 [31]. However, both studies utilized cancer cell lines with wild type IDH1 into which the mutant IDH1 was introduced. To address this issue, we studied HT1080, a fibrosarcoma cell line carrying a native $I D H 1^{R 132 C}$ heterozygous mutation, and found that selectively knocking down mutant IDH1 inhibited cell growth. The critical role the mutant allele is playing in cell survival strongly infers that mutant IDH1 can be used as a practical therapeutic target against IDHI mutated cancers.

\section{RESULTS}

\section{Knockdown of both wild type and mutant IDHI expression inhibits HT1080 cell proliferation}

To assess whether mutant and wild type IDH1 contribute to IDH1 mutated tumor cell growth, we created an IDH1 inducible knockdown cell line utilizing the fibrosarcoma cell line, HT1080 which harbors a heterozygous $I D H 1^{R 132 C}$ mutation. Lentivirus encoding a tetracycline-inducible shRNA targeting the 3' noncoding mRNA of IDH1 was used to generate IDH1 inducible knockdown cell lines. As shown in Figure 1, treatment with $200 \mathrm{ng} / \mathrm{ml}$ tetracycline for 96 hours efficiently knocked down both wild type and mutant IDH1 expression in three different IDH1 inducible knockdown HT1080 clones by the shRNA. Decreased IDH1 expression led

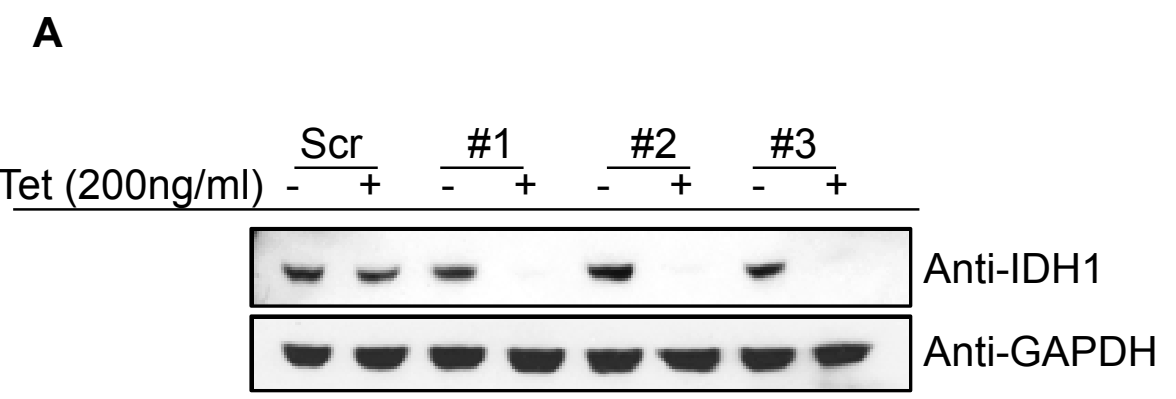

B

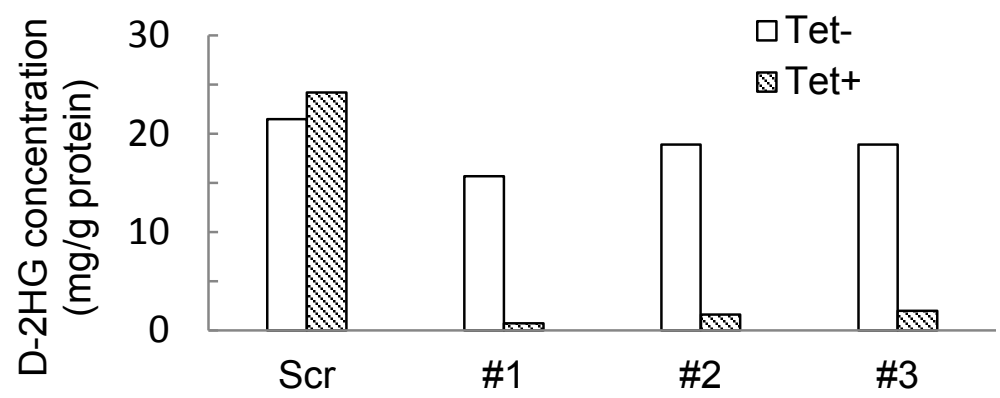

Figure 1: Establishment of IDH1 inducible knockdown HT1080 cell lines. A, Western blot detection of IDH1 in three different clones following treatment with $200 \mathrm{ng} / \mathrm{mL}$ tetracycline for 96 hours. B, D-2HG concentration in cell lysates following treatment with $200 \mathrm{ng} / \mathrm{mL}$ tetracycline for 96 hours. 
to a ten-fold decrease in levels of D-2HG (Figure 1B). We assessed the proliferative activities of the clones and observed a substantial decrease $(62.12 \% \pm 6.93 \%)$ in proliferation following IDH1 knockdown by tetracycline (Figure 2A). Colony formation assays confirmed our finding that HT1080 cells exhibited decreased clonogenic survival $(81.9 \% \pm 13.54 \%)$ upon IDH1 knockdown by tetracycline. Additionally, compared to the scrambled shRNA control, colonies that did form following IDH1 knockdown were smaller in size (Figure 2B).

\section{Mutant IDH1 ${ }^{\mathrm{R} 132 \mathrm{C}}$ is critical for tumor cell proliferation}

The above shRNA used is unable to distinguish between mutant or wild type IDH1. To further reveal the role of mutant IDH1 in cell proliferation, we established multiple cell lines in which we specifically expressed either mutant or wild type IDH1 while knocking down endogenous IDH1 and IDH1 $1^{\mathrm{R} 132 \mathrm{C}}$ in HT1080 by tetracycline induction. This allowed for the simulation of a specific knockdown of either wild type or mutant IDH1, depending on which was being exogenously expressed. First, to generate stable cell lines that exogenously express either wild type IDH1 or mutant IDH1 $1^{\mathrm{R} 132 \mathrm{C}}$, we introduced full-length $I D H 1$ or $I D H 1^{R I 32 C} \mathrm{cDNA}$ missing the 3 ' noncoding region, and with the addition of a V5

A
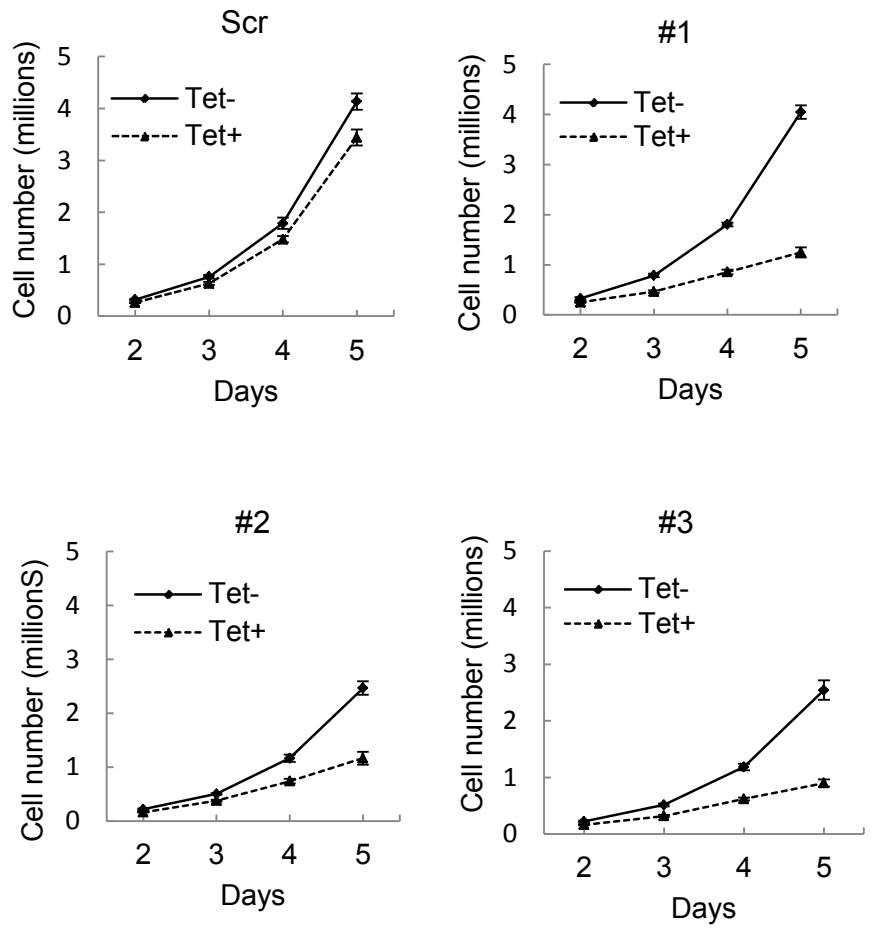

Figure 2: Knocking down IDH1 expression inhibits HT1080 cell growth. A, 50,000 cells were seeded into $100 \mathrm{~mm}$ cell culture dishes, with 0 or $200 \mathrm{ng} / \mathrm{mL}$ tetracycline. Cells were collected and counted daily for five days. Studies were done with biological triplicates. B, 300 cells were plated into $60 \mathrm{~mm}$ cell culture dishes. After 8-10 days, cell colonies were stained with $0.05 \%$ crystal violet. Every treatment was completed in biological triplicate. Representative cell culture dishes are shown.
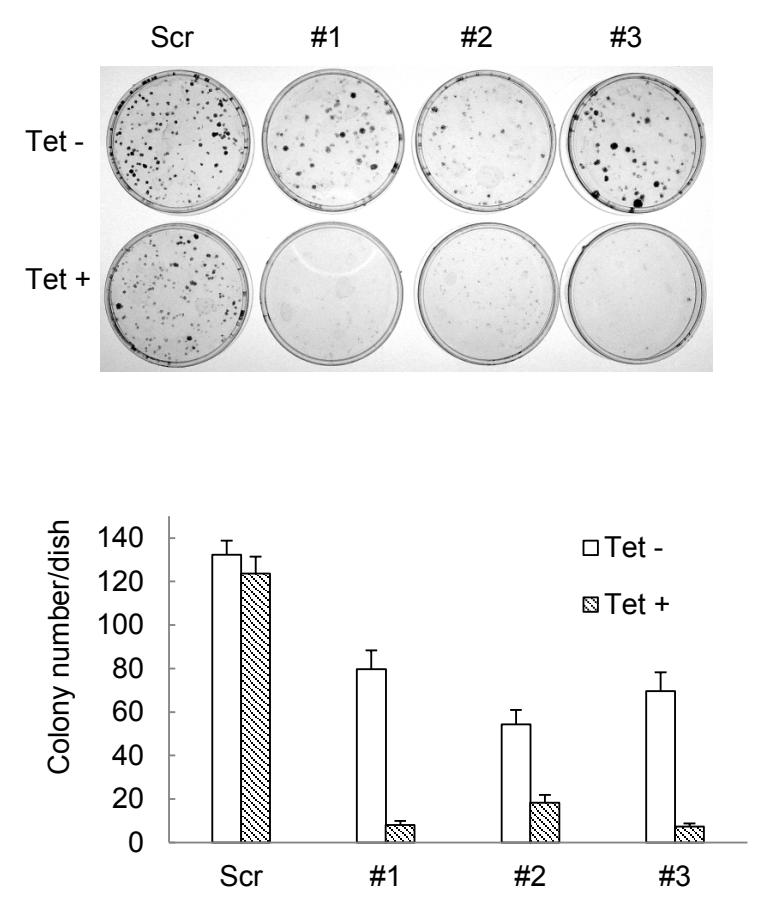

tag, to HT1080 cells. Second, we infected these same cell lines with lentivirus containing an inducible shRNA targeting the IDHI 3' noncoding region. This led to the inducible knockdown of both endogenous wild type DH1 and endogenous IDH1 ${ }^{\mathrm{R} 132 \mathrm{C}}$, but left the exogenous, iral-mediated expression of IDH1 or IDH $1^{\mathrm{R}}$ act, subsequently allowing for the simulation of ific knockdown of IDH1 $1^{\mathrm{R} 132 \mathrm{C}}$ or IDH1, respectively 3A). Western blot assay revealed that tetracycline 3B) Knock of also decreased the D-2HG concentration in HT1080 cells (Figure 3C). Cell proliferation assays revealed that knocking down endogenous wild type and mutant $I D H 1$ expression while maintaining exogenous wild type $I D H 1$ expression in HT1080 inhibited cell growth $(52.20 \% \pm$ $15.73 \%)$. On the contrary, knocking down endogenous wild type and mutant IDH1 while maintaning exogenous IDH $1^{\mathrm{R} 132 \mathrm{C}}$ expression in HT1080 had a minimal effect on cell proliferation (Figure 4A,B). This observation was further confirmed by colony formation assay (Figure 4C). Fluorescence Activated Cell Sorting (FACS) cell cycle analysis revealed that knocking down endogenous mutant and wild type IDH1 expression while maintaining exogenous wild type IDH1 expression in HT1080 arrested

B 
A
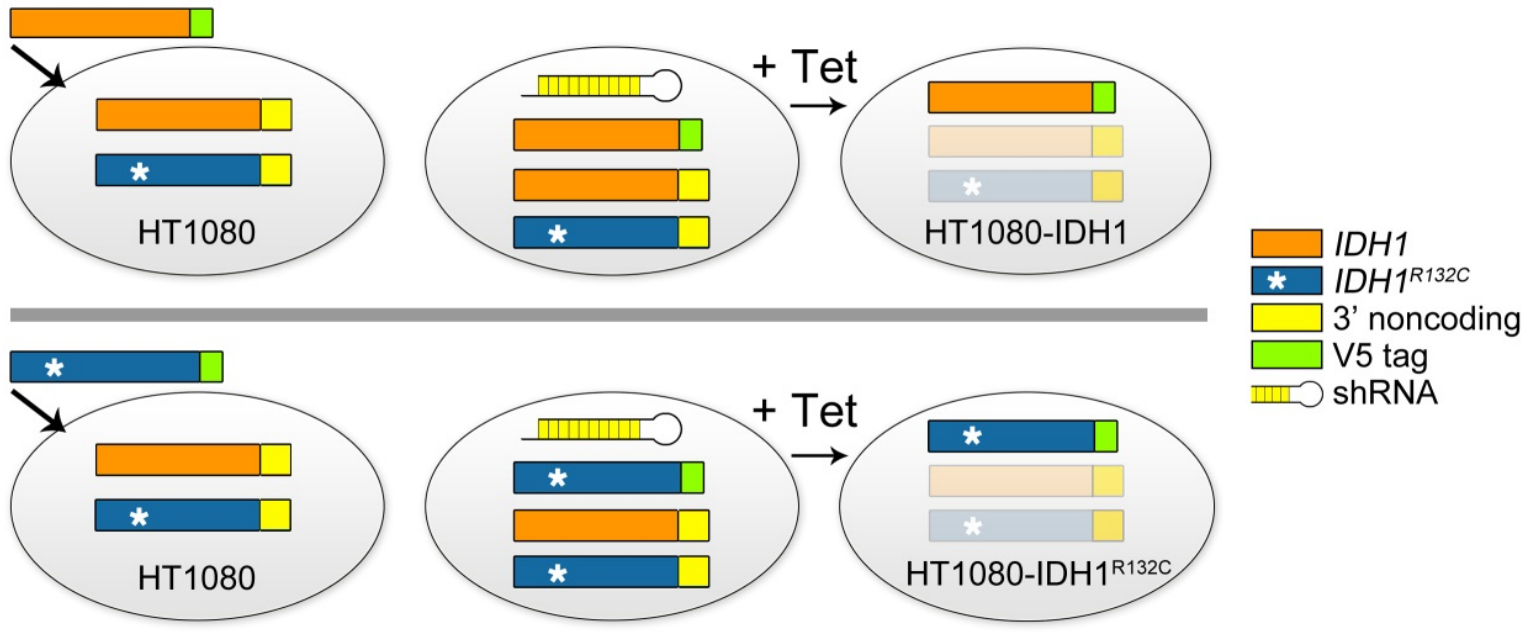

B
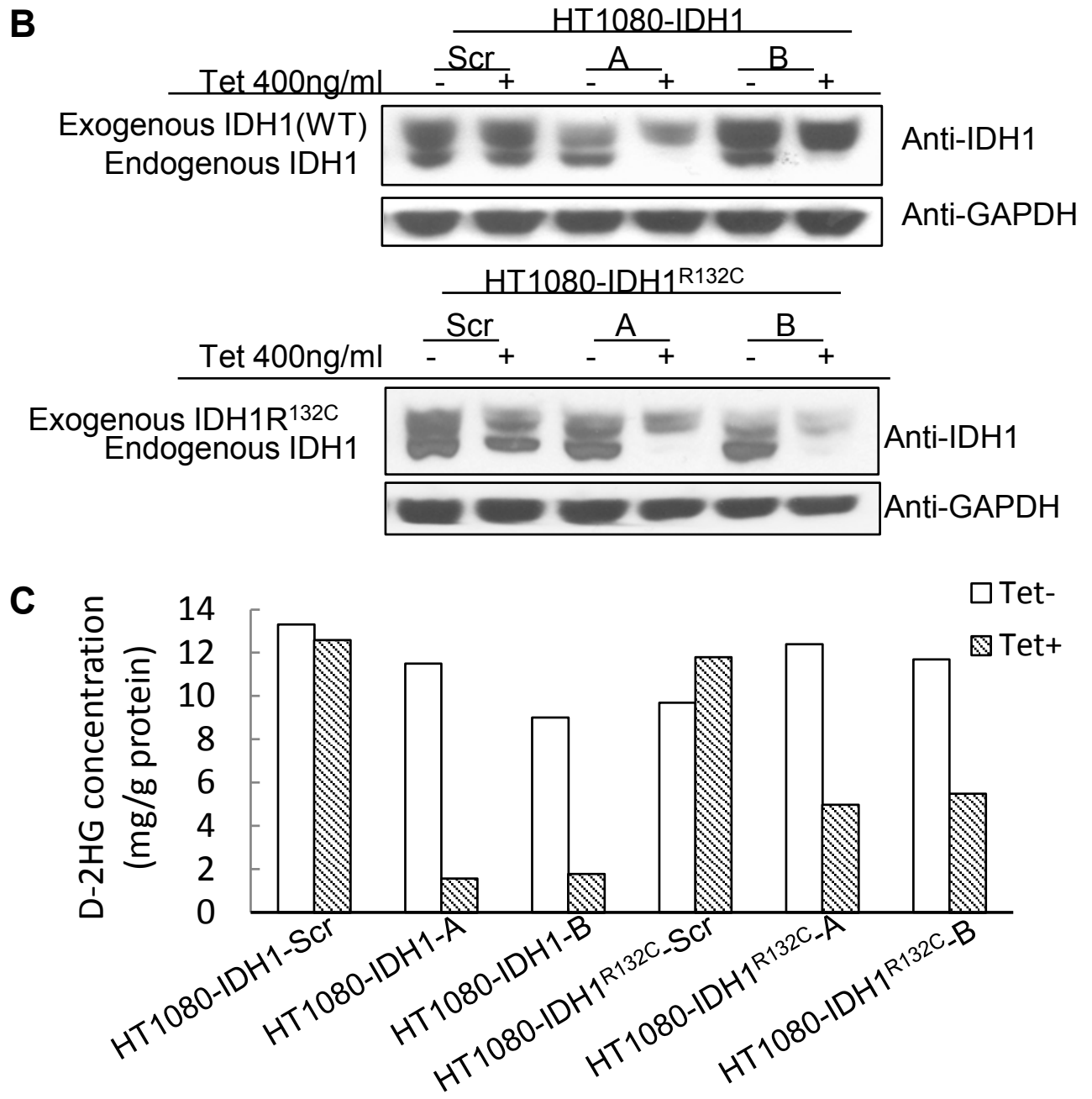

Figure 3: Generation of cell lines with inducible knockdown of mutant or wild type IDH1. A, Strategy for generating cell lines with inducible knockdown of mutant or wild type IDH1. IDH1 or IDH1 ${ }^{\text {R132C }}$ full-length cDNA containing a V5 tag and lacking the 3' non-coding sequence was infected into HT1080 cells and selected for to generate stable cell lines that exogenously express IDH1 or IDH1 ${ }^{\mathrm{R} 132 \mathrm{C}}$. A tetracycline-inducible knockdown vector containing a shRNA sequence specific for the IDH1 3' non-coding sequence was used to infect the stable cell lines that exogenously express IDH1 or IDH1 ${ }^{\mathrm{R} 132 \mathrm{C}}$. Following treatment with tetracycline, the endogenous pools of wild type and mutant IDH1 were ablated, while expression of exogenous IDH1 or IDH1 ${ }^{\mathrm{R} 132 \mathrm{C}}$ remained intact; thereby allowing for the study of the effects of wild type or mutant IDH1 knockdown. B, Cell lines with knockdown of either wild type IDH1 or IDH1 ${ }^{\mathrm{R} 132 \mathrm{C}}$ as identified by Western blot following a 96 hour treatment with tetracycline. C, D-2HG concentration in cell lysates following $200 \mathrm{ng} / \mathrm{mL}$ tetracycline treatment for 96 hours. 
A

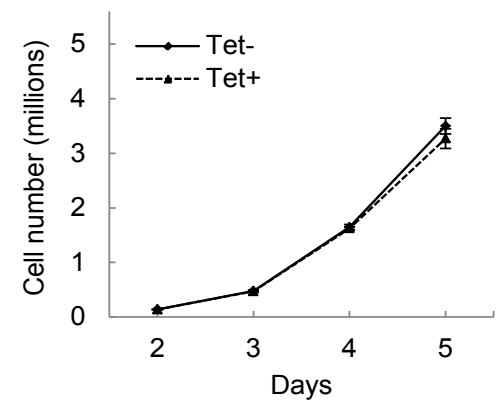

B

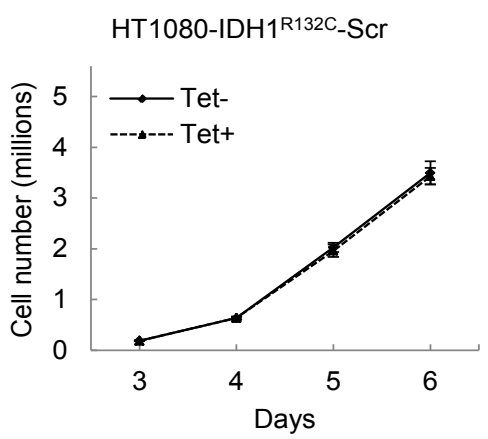

HT1080-IDH1-A
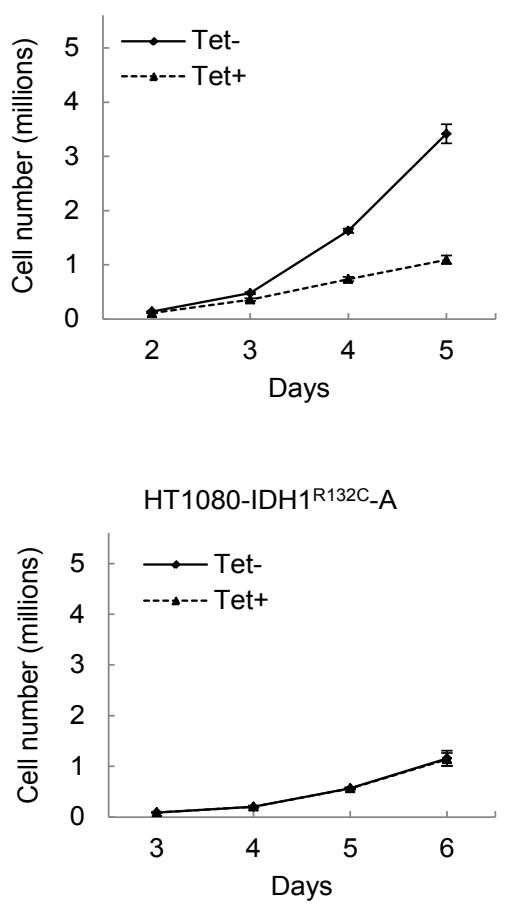

HT1080-IDH1-B
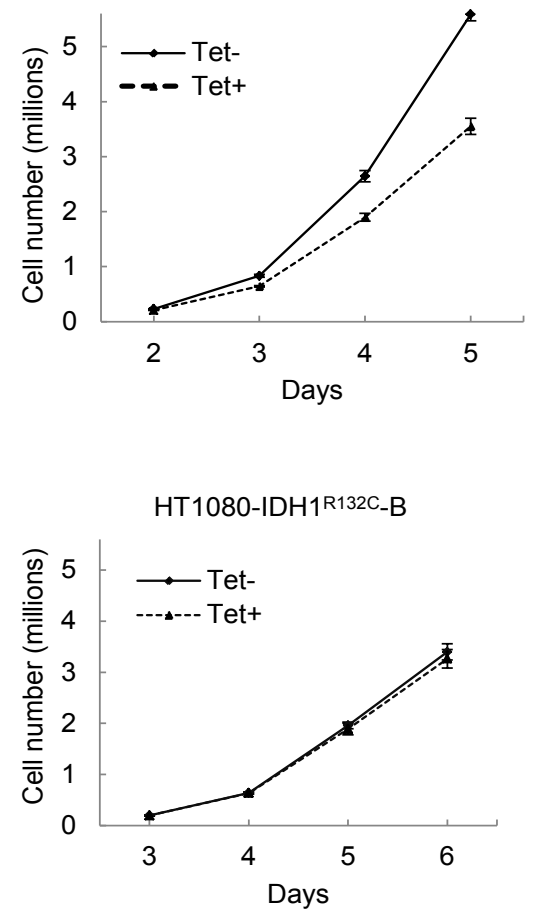

C
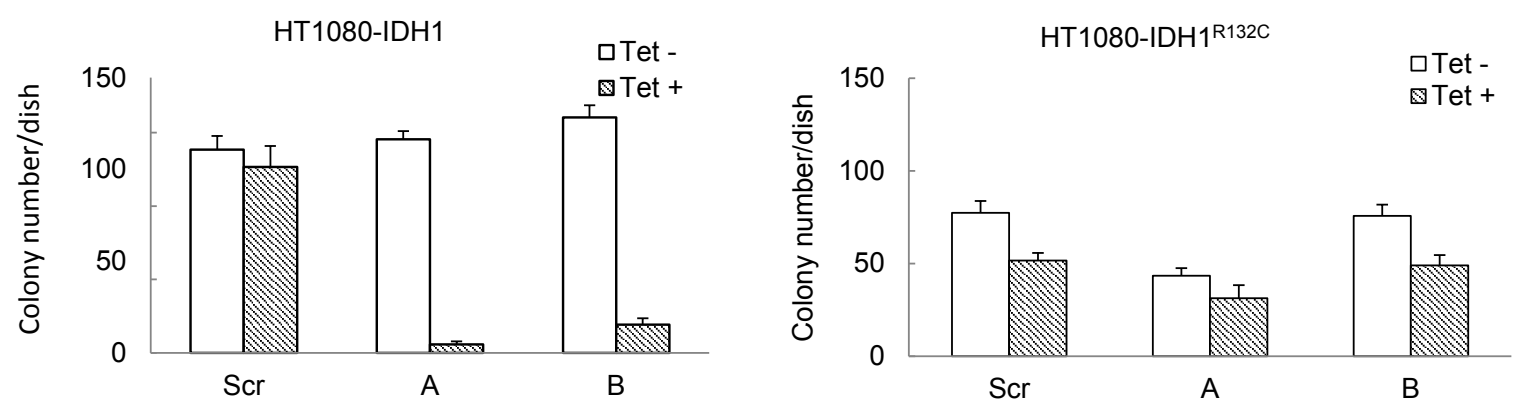

D
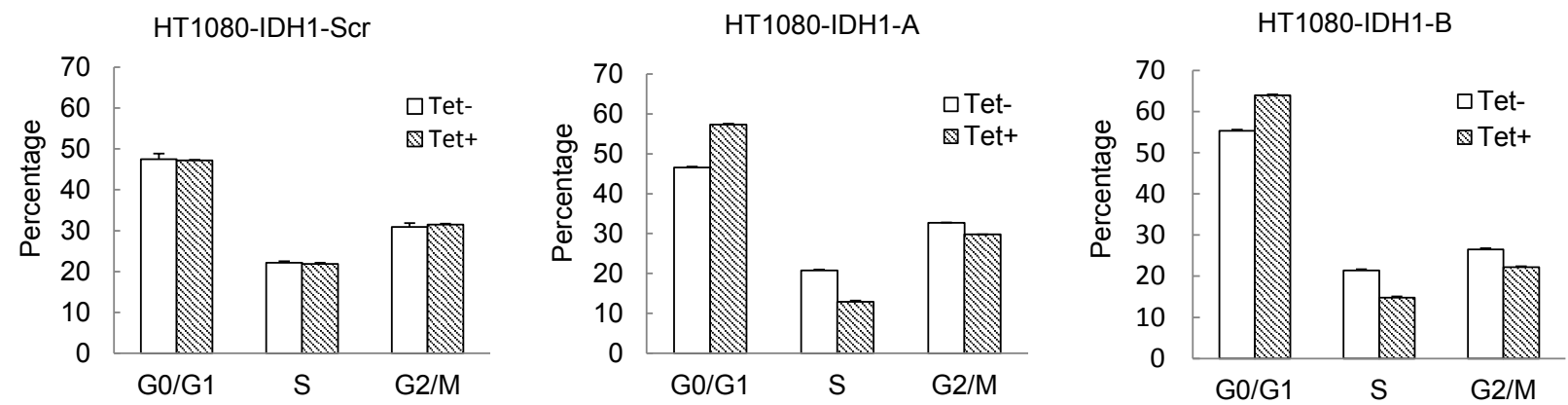

Figure 4: Knocking down mutant IDH1 ${ }^{\mathrm{R} 132 \mathrm{C}}$ inhibits cell growth in vitro. A, 50,000 cells with exogenous wild type IDH1 expression and inducible knockdown of endogenous IDH1 were seeded in $100 \mathrm{~mm}$ cell culture dishes in triplicate and treated with 0 or $200 \mathrm{ng} / \mathrm{mL}$ tetracycline. Cells were collected and counted daily for 5 days. Error bars represent one standard deviation. B, 50,000 cells with exogenous $I D H 1^{R I 32 C}$ expression and inducible knockdown of endogenous IDH1 were seeded in $100 \mathrm{~mm}$ cell culture dishes in triplicate and treated with 0 or $200 \mathrm{ng} / \mathrm{mL}$ tetracycline. Cells were collected and counted daily for 6 days. C, 300 cells were plated in $60 \mathrm{~mm}$ cell culture dishes in triplicate. After 8-10 days treatment, cell colonies were stained with $0.05 \%$ crystal violet and counted. D, Indicated cell lines were treated with 0 or $200 \mathrm{ng} / \mathrm{mL}$ for four days in triplicate and fixed. Cell cycle analysis was completed via FACS. 
the cells at the $\mathrm{G}_{0} / \mathrm{G}_{1}$ phase (Figure 4D).

\section{DISCUSSION}

Thus far, studies that have sought to determine the contribution of mutant IDH1 in tumor survival and proliferation have conflicted, making the potential of mutant IDH1 as a therapeutic target difficult to defend. Here, we describe the generation and use of a biologically relevant cell line that simulates the knockdown of either IDH1 or IDH1 ${ }^{\mathrm{R} 132 \mathrm{C}}$. Our system allows us to dissect the relative contribution of wild type and mutant IDH1 in the fibrosarcoma cell line, HT1080 which harbors a heterozygous R132C mutation in $I D H 1$. This system offers insights into the role that mutant IDH1 plays in tumor cell survival and maintenance. Knockdown of mutant IDH1 in the HT1080 tumor cell line confers significant decreases in cellular proliferation, decreases in the onco-metabolite D-2HG, overall decreases in clonogenic potential, as well as an induction of a $\mathrm{G}_{0} / \mathrm{G}_{1}$ cell cycle arrest; thereby suggesting that depletion of mutant IDH1 from an IDH1 mutant tumor cell line decreases the tumorigenic potential of these cells. Because of the specificity of mutant IDH1 to tumor cells and its absence in the surrounding parenchyma, drugs specifically designed to disrupt mutant IDH1 may kill tumor cells with $I D H 1$ mutations while sparing normal tissues. This, together with our findings that mutant IDH1 is critical for cell survival, offers convincing preclinical rationale for utilizing mutant IDH1 as a therapeutic target.

\section{MATERIALS AND METHODS}

\section{Virus}

To express the $I D H 1$ and $I D H 1^{R 132 C}$ transgenes in cells, IDH1 and $I D H 1^{R 132 C}$ missing the $3^{\prime}$ noncoding sequence were cloned into pLenti6.2/V5 (Invitrogen) following the manufacturer's instructions. To generate the IDH1 inducible knockdown vector, the stuffer DNA was removed from pLKO-Tet-On (Novartis) by AgeI/ EcoRI digest and replaced with double-stranded oligos encoding the IDH1 specific shRNA sequences (targeting the IDH1 3' noncoding sequence) with AgeI/EcoRI sites. Viruses were created using these constructs in 293FT cells, following the manufacturer's instructions.

\section{Cell lines}

The fibrosarcoma cell line HT1080 was generated from a fibrosarcoma biopsy taken from a 35 year-old male patient and was provided by Dr. Todd Waldman of Georgetown University [32]. HT1080 cells were cultured in DMEM (Gibco, Cat. No. 11995) with 10\% FBS. To establish IDH1 inducible knockdown cell lines, HT1080 cells were infected with lentivirus encoding a tetracyclineinducible shRNA targeting the 3' noncoding mRNA of IDH1 and selected for with $0.8 \mu \mathrm{g} / \mathrm{ml}$ puromycin for three weeks. The derived clones, HT1080-shRNA clone \#1, $\# 2$, and \#3 were used for subsequent knockdown studies. Lentivirus containing a tetracycline-inducible scrambled shRNA was used as a control.

To determine the contribution of wild type or mutant IDH1, IDH1 or $I D H 1^{R 132 C}$ full-length cDNA with a V5 tag and lacking the 3' non-coding sequence was exogenously expressed in HT1080 cells. Cells were selected with $4 \mu \mathrm{g} / \mathrm{ml}$ blasticidin for three weeks. Infection with tetracycline-inducible shRNA targeting the 3' noncoding mRNA of IDH1 (the same lentivirus described above), depleted endogenous pools of IDH1 and IDH1 ${ }^{\mathrm{R} 132 \mathrm{C}}$. Cells were selected with $0.8 \mu \mathrm{g} / \mathrm{ml}$ puromycin for three weeks. Scrambled shRNA expressing lentivirus was used as a control. Tetracycline (Sigma, St. Louis, MO) was dissolved in PBS and used for shRNA induction.

\section{Western blot}

Total protein was isolated from cultured monolayer cells with M-PER Mammalian Protein Extraction Reagent (Thermo Scientific). Protein concentrations were measured by comparing with Pre-Diluted Protein Assay standards (Thermo Scientific). After incubation at $95^{\circ} \mathrm{C}$ for five minutes, $50 \mu \mathrm{g}$ protein with same volume in 5\% $\beta$-mercaptoethanol Laemmli Sample Buffer (BIORAD) was loaded onto SDS-PAGE and transferred electrophoretically to nitrocellulose membranes (BIORAD). Membranes were blocked with 5\% milk in washing buffer (10 mmol Tris-HCI pH 7.5, $150 \mathrm{mmol}$ $\mathrm{NaCI}, 0.05 \%$ Tween 20 ) at room temperature for two hours. Membranes were then incubated at $4{ }^{\circ} \mathrm{C}$ with antiIDHC (sc49996, Santa Cruz Biotechnology,Santa Cruz, CA 1:2000 dilution) or anti-GAPDH (sc25778, Santa Cruz Biotechnology, Santa Cruz, CA 1:10000 dilution) overnight at $4^{\circ} \mathrm{C}$. Bands were detected using SuperSignal West-Femto Maximum Sensitivity Substrate (Thermo Scientific).

\section{Cell Proliferation and Clonogenic Assays}

For cell proliferation studies, cells were seeded at a density of 50,000 per $100 \mathrm{~mm}$ diameter dish and treated with 0 or $200 \mathrm{ng} / \mathrm{ml}$ tetracycline. After 5-6 days, cells were collected and counted. For clonogenic survival assays, cells were plated in $60 \mathrm{~mm}$ culture dishes (300 cells/dish) and treated with 0 or $200 \mathrm{ng} / \mathrm{mL}$ tetracycline for $8-10$ days. Cell colonies were stained with $0.05 \%$ crystal violet (Sigma) for one hour and then washed with water. Assays were completed in triplicate.

\section{Cell-cycle Analysis}

Cells were induced with 0 or $200 \mathrm{ng} / \mathrm{mL}$ tetracycline for four days, collected, fixed in $70 \%$ ice-cold ethanol for 24 hours, and treated with $20 \mu \mathrm{g} / \mathrm{mL}$ propidium iodide, $0.1 \%(\mathrm{v} / \mathrm{v})$ Triton X-100, and $100 \mu \mathrm{g} / \mathrm{mL}$ DNase-free RNase A for 20 minutes. Samples were analyzed by BD FACSCalibur. 


\section{ACKNOWLEDGMENTS}

The authors would like to thank Dr. Todd Waldman from Georgetown University for providing us the HT1080 cell line, Ping Fan from Duke University for assistance with targeted mass LC-MS/MS, and Joseph Webb for critical feedback on the manuscript. This project was supported by NIH R01 CA140316, 1R43CA141803, American Cancer Society RSG-10-126-01-CCE, Voices Against Brain Cancer, The V Foundation, The ABC2 Foundation, and the James S. McDonnell Foundation.

\section{Conflict of Interest Statement:}

H. Yan receives research funding and a consulting fee from Sanofi-Aventis for research related to IDH1 mutations.

\section{REFERENCE}

1. Parsons DW, Jones S, Zhang X, Lin JC, Leary RJ, Angenendt P, Mankoo P, Carter H, Siu IM, Gallia GL, Olivi A, McLendon R, Rasheed BA, Keir S, Nikolskaya T, Nikolsky Y, Busam DA, Tekleab H, Diaz LA, Jr., Hartigan J, Smith DR, Strausberg RL, Marie SK, Shinjo SM, Yan H, Riggins GJ, Bigner DD, Karchin R, Papadopoulos N, Parmigiani G, Vogelstein B, Velculescu VE and Kinzler KW. An integrated genomic analysis of human glioblastoma multiforme. Science. 2008. 321: 1807-1812.

2. Balss J, Meyer J, Mueller W, Korshunov A, Hartmann. $\mathrm{C}$ and von Deimling A Analysis of the IDH1 codon 132 mutation in brain tumors. Acta Neuropathol. 2008. 116: 597-602.

3. Yan H, Parsons DW, Jin G, McLendon R, Rasheed BA, Yuan W, Kos I, Batinic-Haberle I, Jones S, Riggins GJ, Friedman H, Friedman A, Reardon D, Herndon J, Kinzler KW, Velculescu VE, Vogelstein B and Bigner DD. IDH1 and IDH2 mutations in gliomas. N Engl J Med. 2009. 360: 765-773.

4. Bleeker FE, Lamba S, Leenstra S, Troost D, Hulsebos T, Vandertop WP, Frattini M, Molinari F, Knowles M, Cerrato A, Rodolfo M, Scarpa A, Felicioni L, Buttitta F, Malatesta S, Marchetti A and Bardelli A. IDH1 mutations at residue p.R132 (IDH1(R132)) occur frequently in high-grade gliomas but not in other solid tumors. Hum Mutat. 2009. 30: 7-11.

5. Hartmann C, Meyer J, Balss J, Capper D, Mueller W, Christians A, Felsberg J, Wolter M, Mawrin C, Wick W, Weller M, Herold-Mende C, Unterberg A, Jeuken JW, Wesseling $\mathrm{P}$, Reifenberger $\mathrm{G}$ and von Deimling A. Type and frequency of IDH1 and IDH2 mutations are related to astrocytic and oligodendroglial differentiation and age: a study of 1,010 diffuse gliomas. Acta Neuropathol. 2009. 118: 469-474.
6. Mardis ER, Ding L, Dooling DJ, Larson DE, McLellan MD, Chen K, Koboldt DC, Fulton RS, Delehaunty KD, McGrath SD, Fulton LA, Locke DP, Magrini VJ, Abbott RM, Vickery TL, Reed JS, Robinson JS, Wylie T, Smith SM, Carmichael L, Eldred JM, Harris CC, Walker J, Peck JB, Du F, Dukes AF, Sanderson GE, Brummett AM, Clark E, McMichael JF, Meyer RJ, Schindler JK, Pohl CS, Wallis JW, Shi X, Lin L, Schmidt H, Tang Y, Haipek C, Wiechert ME, Ivy JV, Kalicki J, Elliott G, Ries RE, Payton JE, Westervelt P, Tomasson MH, Watson MA, Baty J, Heath S, Shannon WD, Nagarajan R, Link DC, Walter MJ, Graubert TA, DiPersio JF, Wilson RK and Ley TJ. Recurring mutations found by sequencing an acute myeloid leukemia genome. N Engl J Med. 2009. 361: 1058-1066.

7. Marcucci G, Maharry K, Wu YZ, Radmacher MD, Mrozek K, Margeson D, Holland KB, Whitman SP, Becker H, Schwind S, Metzeler KH, Powell BL, Carter TH, Kolitz JE, Wetzler M, Carroll AJ, Baer MR, Caligiuri MA, Larson RA and Bloomfield CD. IDH1 and IDH2 gene mutations identify novel molecular subsets within de novo cytogenetically normal acute myeloid leukemia: a Cancer and Leukemia Group B study. J Clin Oncol. 2010. 28: 2348-2355.

8. Paschka P, Schlenk RF, Gaidzik VI, Habdank M, Kronke J, Bullinger L, Spath D, Kayser S, Zucknick M, Gotze K, Horst HA, Germing U, Dohner H and Dohner K. IDH1 and IDH2 mutations are frequent genetic alterations in acute myeloid leukemia and confer adverse prognosis in cytogenetically normal acute myeloid leukemia with NPM1 mutation without FLT3 internal tandem duplication. J Clin Oncol. 2010. 28: 3636-3643.

9. Tefferi A, Lasho TL, Abdel-Wahab O, Guglielmelli P, Patel J, Caramazza D, Pieri L, Finke CM, Kilpivaara O, Wadleigh M, Mai M, McClure RF, Gilliland DG, Levine RL, Pardanani A and Vannucchi AM. IDH1 and IDH2 mutation studies in 1473 patients with chronic-, fibrotic- or blast-phase essential thrombocythemia, polycythemia vera or myelofibrosis. Leukemia. 2010. 24: 1302-1309.

10. Amary MF, Bacsi K, Maggiani F, Damato S, Halai D, Berisha F, Pollock R, O’Donnell P, Grigoriadis A, Diss T, Eskandarpour M, Presneau N, Hogendoorn PC, Futreal A, Tirabosco R and Flanagan AM. IDH1 and IDH2 mutations are frequent events in central chondrosarcoma and central and periosteal chondromas but not in other mesenchymal tumours. J Pathol. 2011. 224: 334-343.

11. Borger DR, Tanabe KK, Fan KC, Lopez HU, Fantin VR, Straley KS, Schenkein DP, Hezel AF, Ancukiewicz M, Liebman HM, Kwak EL, Clark JW, Ryan DP, Deshpande V, Dias-Santagata D, Ellisen LW, Zhu AX and Iafrate AJ. Frequent mutation of isocitrate dehydrogenase (IDH) 1 and IDH2 in cholangiocarcinoma identified through broadbased tumor genotyping. Oncologist. 2012. 17: 72-79.

12. Pansuriya TC, van Eijk R, d'Adamo P, van Ruler MA, Kuijjer ML, Oosting J, Cleton-Jansen AM, van Oosterwijk JG, Verbeke SL, Meijer D, van Wezel T, Nord KH, 
Sangiorgi L, Toker B, Liegl-Atzwanger B, San-Julian M, Sciot R, Limaye N, Kindblom LG, Daugaard S, Godfraind C, Boon LM, Vikkula M, Kurek KC, Szuhai K, French PJ and Bovee JV. Somatic mosaic IDH1 and IDH2 mutations are associated with enchondroma and spindle cell hemangioma in Ollier disease and Maffucci syndrome. Nat Genet. 2011. 43: 1256-1261.

13. Amary MF, Damato S, Halai D, Eskandarpour M, Berisha F, Bonar F, McCarthy S, Fantin VR, Straley KS, Lobo S, Aston W, Green CL, Gale RE, Tirabosco R, Futreal A, Campbell P, Presneau N and Flanagan AM. Ollier disease and Maffucci syndrome are caused by somatic mosaic mutations of IDH1 and IDH2. Nat Genet. 2011. 43: 12621265.

14. Kang MR, Kim MS, Oh JE, Kim YR, Song SY, Seo SI, Lee JY, Yoo NJ and Lee SH. Mutational analysis of IDH1 codon 132 in glioblastomas and other common cancers. Int J Cancer. 2009. 125: 353-355.

15. Sjoblom T, Jones S, Wood LD, Parsons DW, Lin J, Barber TD, Mandelker D, Leary RJ, Ptak J, Silliman N, Szabo S, Buckhaults P, Farrell C, Meeh P, Markowitz SD, Willis J, Dawson D, Willson JK, Gazdar AF, Hartigan J, Wu L, Liu C, Parmigiani G, Park BH, Bachman KE, Papadopoulos N, Vogelstein B, Kinzler KW and Velculescu VE. The consensus coding sequences of human breast and colorectal cancers. Science. 2006. 314: 268-274.

16. Lopez GY, Reitman ZJ, Solomon D, Waldman T, Bigner DD, McLendon RE, Rosenberg SA, Samuels Y and Yan H. IDH1(R132) mutation identified in one human melanoma metastasis, but not correlated with metastases to the brain. Biochem Biophys Res Commun. 2010. 398: 585-587.

17. Kranendijk M, Struys EA, van Schaftingen E, Gibson KM, Kanhai WA, van der Knaap MS, Amiel J, Buist NR, Das AM, de Klerk JB, Feigenbaum AS, Grange DK, Hofstede FC, Holme E, Kirk EP, Korman SH, Morava E, Morris A, Smeitink J, Sukhai RN, Vallance H, Jakobs C and Salomons GS. IDH2 mutations in patients with D-2-hydroxyglutaric aciduria. Science. 2010. 330: 336.

18. Watanabe T, Nobusawa S, Kleihues $\mathrm{P}$ and Ohgaki H. IDH1 mutations are early events in the development of astrocytomas and oligodendrogliomas. Am J Pathol. 2009. 174: 1149-1153.

19. Kosmider O, Gelsi-Boyer V, Slama L, Dreyfus F, BeyneRauzy O, Quesnel B, Hunault-Berger M, Slama B, Vey N, Lacombe C, Solary E, Birnbaum D, Bernard OA and Fontenay M. Mutations of IDH1 and IDH2 genes in early and accelerated phases of myelodysplastic syndromes and MDS/myeloproliferative neoplasms. Leukemia. 2010. 24: 1094-1096.

20. Jin G, Reitman ZJ, Spasojevic I, Batinic-Haberle I, Yang J, Schmidt-Kittler O, Bigner DD and Yan H. 2-hydroxyglutarate production, but not dominant negative function, is conferred by glioma-derived NADP-dependent isocitrate dehydrogenase mutations. PLoS One. 2011. 6: e16812.
21. Dang L, White DW, Gross S, Bennett BD, Bittinger MA, Driggers EM, Fantin VR, Jang HG, Jin S, Keenan MC, Marks KM, Prins RM, Ward PS, Yen KE, Liau LM, Rabinowitz JD, Cantley LC, Thompson CB, Vander Heiden MG and Su SM. Cancer-associated IDH1 mutations produce 2-hydroxyglutarate. Nature. 2009. 462: 739-744.

22. Gross S, Cairns RA, Minden MD, Driggers EM, Bittinger MA, Jang HG, Sasaki M, Jin S, Schenkein DP, Su SM, Dang L, Fantin VR and Mak TW. Cancer-associated metabolite 2-hydroxyglutarate accumulates in acute myelogenous leukemia with isocitrate dehydrogenase 1 and 2 mutations. J Exp Med. 2010. 207: 339-344.

23. Sellner L, Capper D, Meyer J, Langhans CD, Hartog CM, Pfeifer H, Serve H, Ho AD, Okun JG, Kramer A and Von Deimling A . Increased levels of 2-hydroxyglutarate in AML patients with IDH1-R132H and IDH2-R140Q mutations. Eur J Haematol. 2010. 85: 457-459.

24. Noushmehr H, Weisenberger DJ, Diefes K, Phillips HS, Pujara K, Berman BP, Pan F, Pelloski CE, Sulman EP, Bhat KP, Verhaak RG, Hoadley KA, Hayes DN, Perou CM, Schmidt HK, Ding L, Wilson RK, Van Den Berg D, Shen H, Bengtsson H, Neuvial P, Cope LM, Buckley J, Herman JG, Baylin SB, Laird PW and Aldape K. Identification of a $\mathrm{CpG}$ island methylator phenotype that defines a distinct subgroup of glioma. Cancer Cell. 2010. 17: 510-522.

25. Laffaire J, Everhard S, Idbaih A, Criniere E, Marie Y, de Reynies A, Schiappa R, Mokhtari K, Hoang-Xuan K, Sanson M, Delattre JY, Thillet J and Ducray F. Methylation profiling identifies 2 groups of gliomas according to their tumorigenesis. Neuro Oncol. 2011. 13: 84-98.

26. Christensen BC, Smith AA, Zheng S, Koestler DC, Houseman EA, Marsit CJ, Wiemels JL, Nelson HH, Karagas MR, Wrensch MR, Kelsey KT and Wiencke JK. DNA methylation, isocitrate dehydrogenase mutation, and survival in glioma. J Natl Cancer Inst. 2011. 103: 143-153.

27. Figueroa ME, Abdel-Wahab O, Lu C, Ward PS, Patel J, Shih A, Li Y, Bhagwat N, Vasanthakumar A, Fernandez HF, Tallman MS, Sun Z, Wolniak K, Peeters JK, Liu W, Choe SE, Fantin VR, Paietta E, Lowenberg B, Licht JD, Godley LA, Delwel R, Valk PJ, Thompson CB, Levine RL and Melnick A .Leukemic IDH1 and IDH2 mutations result in a hypermethylation phenotype, disrupt TET2 function, and impair hematopoietic differentiation. Cancer Cell. 2010. 18: 553-567.

28. Xu W, Yang H, Liu Y, Yang Y, Wang P, Kim SH, Ito S, Yang C, Xiao MT, Liu LX, Jiang WQ, Liu J, Zhang JY, Wang B, Frye S, Zhang Y, Xu YH, Lei QY, Guan KL, Zhao SM and Xiong Y. Oncometabolite 2-hydroxyglutarate is a competitive inhibitor of alpha-ketoglutarate-dependent dioxygenases. Cancer Cell. 2011. 19: 17-30.

29. Lu C, Ward PS, Kapoor GS, Rohle D, Turcan S, AbdelWahab O, Edwards CR, Khanin R, Figueroa ME, Melnick A, Wellen KE, O'Rourke DM, Berger SL, Chan TA, Levine RL, Mellinghoff IK and Thompson CB. IDH mutation impairs histone demethylation and results in a block to cell 
differentiation. Nature. 2012. 483: 474-478.

30. Shibata T, Kokubu A, Miyamoto M, Sasajima Y and Yamazaki N. Mutant IDH1 confers an in vivo growth in a melanoma cell line with BRAF mutation. Am J Pathol. 2011. 178: 1395-1402.

31. Bralten LB, Kloosterhof NK, Balvers R, Sacchetti A, Lapre L, Lamfers M, Leenstra S, de Jonge H, Kros JM, Jansen EE, Struys EA, Jakobs C, Salomons GS, Diks SH, Peppelenbosch M, Kremer A, Hoogenraad CC, Smitt PA and French PJ. IDH1 R132H decreases proliferation of glioma cell lines in vitro and in vivo. Ann Neurol. 2011. 69: 455-463.

32. Rasheed S, Nelson-Rees WA, Toth EM, Arnstein P and Gardner MB. Characterization of a newly derived human sarcoma cell line (HT-1080). Cancer. 1974. 33: 1027-1033. 